\title{
Factors Affecting Firm Competitiveness: Evidence from an Emerging Market
}

\author{
Elif Akben-Selcuk
}

Department of Business Administration, Kadir Has University, Istanbul, 34083, Turkey; elif.akben@khas.edu.tr; Tel.: +90-212-533-6532

Academic Editor: Nicholas Apergis

Received: 25 January 2016; Accepted: 5 May 2016; Published: 9 May 2016

\begin{abstract}
The objective of this study is to investigate the factors affecting firm competitiveness in an emerging market-Turkey. In the paper, competitiveness is proxied by a firm's financial performance. The empirical analysis is based on firms listed on Borsa Istanbul and covers the period between 2005 and 2014. Results from a firm-level panel data model indicate that return on assets is positively related to firm size, international sales, liquidity and growth, and negatively related to leverage and R\&D expenditures. On the other hand, gross profit margin is positively related to size and international sales, and negatively related to leverage and R\&D expenditures. Finally, results show that Tobin's $Q$ ratio is higher for firms with higher levels of debt and higher liquidity levels.
\end{abstract}

Keywords: financial performance; profitability; return on assets; gross profit margin; Tobin's Q; panel data; fixed effects model; Turkey

JEL: G30, G32

\section{Introduction}

In today's turbulent economic environment, competitiveness has become more important than ever for a firm's survival and success. Although firm competitiveness is a very popular term among practitioners and academicians, there is no agreement on its meaning.

In the academic literature, the term "firm competitiveness" has been defined in several ways. Porter [1] defines competitiveness as the ability of a given firm to successfully compete in a given business environment. Lall [2] defines firm competitiveness as the ability of a firm to do better than benchmark companies in terms of profitability, sales, or market share. Similarly, Buckley, Pass, and Prescott [3] consider competitiveness to be synonymous with a firm's long-run profit performance, its ability to compensate employees and generate superior returns for shareholders. In line with these definitions, this study will focus on the financial performance of a firm to measure its competitiveness. In general, the existence of good financial performance suggests that the firm is doing better in terms of competitiveness since profitable opportunities result in higher production and sales. The advantage of employing financial measures is their agreed-upon definitions and the easiness of calculations [4].

Depperu and Cerrato [5] propose a matrix framework to define competitiveness based on two dimensions. The first dimension is related to the way the term is intended. In other words, competitiveness could either be considered as a driver of firm performance or as an outcome variable. The second dimension called "approach" distinguishes between static and dynamic analysis of competitiveness. Based on this framework, we define competitiveness as an outcome variable and adopt a static approach. Accordingly, the objective of this paper is to investigate the factors that have an effect on financial performance and therefore competitiveness in an emerging market, Turkey. So far, the majority of the studies on the determinants of firm level competitiveness used samples from developed countries. Given the different regulatory and competitive environments prevalent 
in emerging markets, the results could be different. In that respect, Turkey, as a rapidly developing emerging market, provides an ideal environment to test the validity of the results obtained in developed countries on the factors affecting firm level competitiveness.

The remainder of the paper is organized as follows. First, a review of the literature on the determinants of financial performance in both developed and emerging countries is provided. The methodology is elaborated in the next section. Then, estimation results are presented. The final section concludes the paper with a summary of main findings as well as their implications and recommendations for further research.

\section{Literature Review}

The determinants of financial performance have been studied by researchers from various disciplines including economics, strategic management, accounting and finance, since very early on [6-8]. In general, findings suggested that profitability measures tend to converge towards long run average values that are specific to each firm $[9,10]$. In their meta-analysis, Capon, Farley, and Hoenig [11] reviewed 320 empirical studies and identified several strategic, environmental and organizational factors affecting financial performance. According to the results reported by the authors, industry concentration, growth, market share, geographic dispersion of production, research and development expenditures and size measured by sales have a positive impact on the financial performance of the companies. On the contrary, the majority of the studies analyzed reported a negative relationship between financial performance and variables such as debt, diversification, imports and exports. Subsequently, many more recent studies investigated these and additional factors as potential determinants of financial performance. The focus of this paper will be on firm-specific determinants of financial performance or profitability; hence, findings from studies taking that approach will be discussed below. Focusing on firm specific factors seems more appropriate for this study since prior research documented that firm characteristics account for more of the variation in the profits of Turkish firms compared to industry effects [12].

In their study, Giovanis and Ozdamar [13] analyzed the determinants of company profitability using the US Compustat database for the years between 1976 and 2009. The authors demonstrated that firm size and debt have positive effects on profitability but only up to a certain point after which the relationship becomes negative. The assets-to-sales, on the other hand, was found to have a negative impact on profitability at the beginning, but, after some point, the relationship becomes negative. In another study focusing on US firms, Tailab [14] analyzed the variation in the financial performance of 100 top non-financial firms listed on the Fortune 500 for the years between 2009 and 2013. Analysis results showed that debt ratio, higher levels of inventory, and growth are negatively related to profitability as measured by return on assets while liquidity and size have a negative impact on profitability.

In a European study, Goddard, Tavakoli, and Wilson [15] analyzed the factors affecting profitability for manufacturing and service sector firms in four countries, namely Belgium, France, Italy and the UK. Focusing on the period 1993-2001 and using dynamic panel data models, the authors showed that firm size and gearing ratio have a negative impact on profitability while the impact of market share and liquidity on profitability is positive.

In their study of Greek firms, Liargovas and Skandalis [4] investigated financial and non-financial determinants of firm competitiveness using a data set of 102 companies listed on the Athens Stock Exchange during the period between 1997 and 2004. The results showed that leverage, centrality of the location, firm size, export activity, liquidity and management competence have a significant impact on firm competitiveness measured by three variables including return on assets, return on equity or return on sales. In a more recent study, Pervan and Visic [16] investigated the antecedents of firm profitability for a sample of 2050 Croatian companies for the 2002-2010 period. Analysis results revealed that firm size and asset turnover have a weak positive influence on firm profitability, while debt ratio has a negative effect on profitability. 
In their study of Slovak companies, Lalinsky [17] designed a survey and used a firm level dynamic panel data model to investigate the factors affecting firm competitiveness proxied by measures of profitability, productivity, export performance and market share. Using annual data for the period 2001-2009, the authors showed that the profitability of the companies, measured by return on assets is affected by their local market share, perceived energy costs, exchange rate stability, the quality of suppliers, and the use of communications technology.

In one of the studies focusing on emerging markets, Mirza and Javed [18] examined the determinants of profitability in a sample of 60 Pakistani firms listed on the Karachi stock exchange for the years between 2007 and 2011. The empirical results documented a significant association between the firm's financial performance and firm specific indicators such as corporate governance, risk management, ownership structure, and capital structure. In another emerging market study, Kakani, Saha, and Reddy [19] analyzed the determinants of firm performance in the Indian market. The sample consisted of 566 large Indian firms and used data for two sub-periods, 1992-1996 and 1996-2000 to investigate Indian firms' financial performance. Analysis results showed that firm size, marketing expenditures, and international diversification had a positive impact on financial performance indicators based on market value. Other significant factors included ownership concentration and leverage.

Studies analyzing the determinants firm competitiveness or financial performance in Turkey are relatively few in number. In one such study, Gurbuz, Aybars, and Kutlu [20] used a sample comprising 164 firm-years of observations for Turkish real sector firms listed on the Istanbul Stock Exchange during the period 2005-2008. The results of panel data regression analyses showed there is a positive association between institutional ownership and financial performance measured by return on assets, with the association being stronger for firms listed on the corporate governance index. In addition, firm size, dividend yield, and current ratio were documented to have a positive impact on financial performance while the impact of leverage and capital intensity on financial performance was found to be negative. Also relevant is the study by Dogan [21] that focused on the impact of firm size on profitability measured by return on assets. Using a dataset of 200 listed companies for the period 2008-2011, a positive relation between firm size and profitability was documented. Liquidity was also demonstrated to have a positive effect on profitability while the impact of firm age and leverage on return on assets have been found to be negative. In a more recent study, Karabag, Lau, and Suvankulov [22] investigated the determinants of competitiveness for Turkish firms operating in the textile and apparel industry. Results of factor analysis identified eight constructs of competitiveness, three of which were considered as the most significant determinants of firm competitiveness in the Turkish textile and apparel industries. These included product differentiation, efforts across foreign markets and state support. Surprisingly, the study showed very little impact of networking on firm competitiveness.

As is clear from the preceding discussion, there is no consensus on the impact of firm specific factors on financial performance. Especially for emerging market firms, the number of studies is limited and results are conflicting. Therefore, the present study will attempt to fill this gap by offering additional empirical evidence from an emerging market, Turkey.

\section{Methodology}

\subsection{Data}

To determine the factors affecting firm competitiveness in Turkey, we collect data on firms listed on Borsa Istanbul from January 2005 to December 2014. The reason for excluding the period before 2005 is due to the fact that the adoption of International Financial Reporting Standards (IFRS) was made mandatory in that year. Hence, financial statements issued before 2005 would be incomparable.

Since the total number of firms in the sample is changing over the years (as a result of M\&A activities, firms newly becoming public or firms which stop being public), the data is unbalanced. The 
minimum number of firms (273) was achieved in 2005 while the maximum number of firms (408) was recorded in 2013. The final sample consisted of 359 firms per year on average and a total of 3591 firm-years of observations.

\subsection{Variables}

As explained in the previous section, a firm's financial performance will be used as a proxy for its competitiveness. Financial performance is measured alternatively with three financial ratios. The first of these, return on assets (ROA), measures the income produced by the total assets of a company. It is helpful for the managers and investors to analyze how efficiently a company can convert its investments in assets into profits. The advantage of this measure is that it is free from bias resulting from differences in capital structure. However, it might be affected by inflation. The second financial performance measure, gross profit margin or gross margin (GM) reflects the percentage of total revenue that the company retains after incurring the cost of goods sold. The gross margin does not suffer from inflation bias. The third measure, Tobin's $Q(T Q)$ is a reflection of the market's expectations about future profitability contrary to return on assets or gross margin, which are related to current profitability. Based on the variables that have been studied in the previous literature, a relationship between financial performance and several explanatory variables is suggested in the following form:

Financial performance $=f($ leverage, liquidity, size, exports, R\&D, growth).

The above relation will be estimated with regression analysis. The coefficients of the explanatory variables are expected to take the following signs: the direction of the relationship between financial performance and leverage cannot be assessed a priori because previous empirical studies have yielded mixed results. While some researchers found a positive relationship [23-25], others demonstrated that firms using more debt in their capital structures have lower financial performance [26-28]. The sign of the liquidity variable could also be positive or negative. Previous studies in the literature showed that while profitability and liquidity are complementary to each other up to a certain point in liquidity, further investments in current assets beyond that point could be detrimental [16,29].

Based on a traditional neoclassical view, firm size is expected to have a positive impact on financial performance. Larger firms are expected to benefit from economies of scale and hence have more competitive power. However, it might also be the case that a large firm size is a result of agency problems. In that case, managers might have expanded their firm in the pursuit of their own interest, resulting in a negative relationship between size and financial performance [16,30,31]. Export activity is anticipated to have a positive impact on financial performance since previous studies showed that exporting firms are more productive than firms that obtain their revenues from the national market [32]. The sign of the R\&D variable is also expected to be positive so that firms investing heavily in research and development activities enjoy better financial performance as a result of increased productivity levels [33]. Finally, the relationship between growth and financial performance is expected to be positive [34].

The calculation methodology for the dependent and independent variables is provided in Table 1 below. In order to account for industry specific effects all variables except exports are calculated as absolute deviations from the industry median. For this adjustment, industries are defined based on two-digit SIC codes. In cases where no industry benchmarks can be found, broader industry classifications provided by Campbell [35] are used. 
Table 1. Calculation methodology for the variables.

\begin{tabular}{cl}
\hline Variable & \multicolumn{1}{c}{ Definition } \\
\hline ROA & $\begin{array}{l}\text { Return on assets, computed by dividing a firm's annual net income by the average of its total assets at } \\
\text { the beginning and at the end of the reporting term. }\end{array}$ \\
\hline GM & Gross margin, computed as net sales revenue minus cost of goods sold divided by net sales revenue. \\
\hline TQ & Tobin's Q, calculated as the market value of the firm's assets divided by their book value. \\
\hline Leverage & The firm's total debt ratio calculated as the ratio of its interest bearing debt to the value of its total assets. \\
\hline Liquidity & The firm's current ratio calculated as the ratio of its current assets divided by its current liabilities. \\
\hline Size & The natural logarithm of the firm's total assets. \\
\hline Exports & $\begin{array}{l}\text { A categorical variable which takes the value of "1" if the firm generates some of its revenues from } \\
\text { international sales, “0" otherwise. }\end{array}$ \\
\hline R\&D & The firm's R\&D expenditures divided by its total revenues. \\
\hline Growth & The percentage change in net sales compared to the previous year. \\
\hline
\end{tabular}

\subsection{Estimation}

Using the variables presented above, three alternative regression equations will be estimated, each regressing one of the three dependent variables on the same set of explanatory variables. Due to the structure of our dataset, panel data estimation will be employed. The model to be estimated is as follows:

$$
\begin{gathered}
Y_{i t}=\mathrm{b}_{0}+\mathrm{b}_{1} X_{i t}+\varepsilon_{i t}, \\
\varepsilon_{i t}=\alpha_{i}+\eta_{i t},
\end{gathered}
$$

where $Y_{i t}$ is one of the financial performance measures (ROA, GM, or TQ) for firm $i$ in year $t, X_{i t}$ is the set of exogenous observable characteristics of the firm $i, b_{0}$ and $b_{1}$ are parameters to be estimated, $\varepsilon_{i t}$ is the error term, $\alpha_{i}$ is the individual effect component of the error term, and $\eta_{i t}$ is the time-variant component of the error term.

Since a cross-sectional heterogeneity is highly probable due to potential omitted variables affecting financial performance, a different intercept should be modeled for each firm. There are two ways to accomplish this: the fixed effects model and the random effects model [36]. The Hausman specification test is the classical test of whether the fixed or random effects model should be used. The research question is whether there is a significant correlation between the unobserved firm-specific random effects and the regressors. If there is no such correlation, then the random effects model may be more powerful and parsimonious. If there is such a correlation, the random effects model would be inconsistently estimated and the fixed effects model would be the model of choice [36].

The Hausman test is a kind of Wald chi-square test with $k$ degrees of freedom (where $k$ equals the number of regressors) on the difference matrix between the variance-covariance of the fixed effects with that of the random effects model. The chi-square statistics are $35.17(p<0.01)$ for the first model (where financial performance is measured by return on assets) $(p<0.01), 26.11$ for the second model (where financial performance is measured by gross margin), and $31.12(p<0.01)$ for the third model (where financial performance is measured by Tobin's Q). Based on these results, the null hypothesis that the random effects estimate is insignificantly different from the fixed effects estimate can be rejected. Therefore, a fixed effects panel data regression will be employed in our analyses. In addition to firm fixed effects, period fixed effects are also added to the model in order to control for the impact of general economic fluctuations. The lagged values of the dependent variables are also included as regressors in order to account for the impact of past profitability. Finally, the variables are winsorized at the 1st and 99th percentile of their pooled distribution across all firm-years [37].

To address potential heteroscedasticity concerns, robust standard errors developed by White [38] will be reported. Regarding the other assumptions of the model, the likelihood ratio test can not reject the null hypothesis of temporal independence $(p=0.238)$ and Pesaran's cross sectional dependence (CD) test can not reject the null hypothesis of spatial independence $(p=0.189)$. Moreover, Table 2 
below reports pairwise correlation coefficients between the independent variables. As can be seen, all coefficients remain below the threshold value of 0.7 ; therefore, multicollinearity is not a concern [39].

Table 2. Correlation matrix.

\begin{tabular}{ccccccc}
\hline & Leverage & Liquidity & Size & Exports & R\&D & Growth \\
\hline Leverage & 1 & & & & & \\
Liquidity & 0.4422 & 1 & & & & \\
$\quad$ Size & 0.2353 & 0.0180 & 1 & & & \\
Exports & 0.1693 & -0.0135 & 0.2072 & 1 & & \\
R\&D & -0.0468 & -0.0294 & -0.0489 & -0.0168 & 1 & \\
Growth & -0.0217 & -0.0353 & -0.0213 & -0.0515 & -0.017 & 1 \\
\hline
\end{tabular}

\section{Empirical Results}

This section will present the results of the regression analysis and discuss the factors which have a significant impact on the financial performance of the firms in the sample as measured by their return on assets, gross margin and Tobin's $Q$ ratios. To begin with, Table 3 presents descriptive statistics on the variables employed in this study. According to these statistics, the average ROA for the sample is $20 \%$, the average GM is $22 \%$ while the average TQ value is recorded as 1.5 . When the independent variables are analyzed, it is seen that the average debt ratio is $45 \%$ while the average current ratio is $85 \%$. The size variable defined as the natural logarithm of total assets registers a mean value of 18.92. In the sample, $58 \%$ of the firms derive some of their revenues from abroad. The ratio of $R \& D$ expenditures to total revenues for an average firm is only $0.4 \%$. Finally, the average growth rate is equal to $21 \%$.

Table 3. Descriptive statistics.

\begin{tabular}{cccccc}
\hline Variable & $N$ & Mean & Std. Dev. & Min & Max \\
\hline Return on Assets & 3578 & 0.20 & 0.15 & -1.67 & 0.84 \\
Gross Margin & 3576 & 0.22 & 0.24 & -1.59 & 1.82 \\
Tobin's Q & 3573 & 1.50 & 1.89 & 0.00 & 18.05 \\
Leverage & 3552 & 0.45 & 0.28 & 0.00 & 1.70 \\
Liquidity & 3575 & 0.85 & 1.22 & 0.00 & 15.95 \\
Size & 3585 & 18.92 & 1.92 & 8.90 & 26.16 \\
Exports & 3590 & 0.58 & 0.49 & 0.00 & 1.00 \\
R\&D & 3416 & 0.004 & 0.02 & 0.00 & 0.63 \\
Growth & 3568 & 0.21 & 1.01 & -1.00 & 15.93 \\
\hline
\end{tabular}

Panel data regression results are presented in Table 4 that follows. According to the results of the first model, which are displayed in Panel A, all the variables in the model are significant in explaining the variation in financial performance when it is measured by ROA. Analysis of coefficients shows that companies with higher levels of leverage have lower ROA values. Liquidity as measured by the firm's current ratio has a positive impact on ROA. The positive and statistically significant coefficient of the size variable shows that as firms become larger, their profitability increases. Firms that derive some of their revenues from international sales have higher ROA, but R\&D expenditures have a negative impact on financial performance. Finally, growth and past profitability have a positive and significant impact on current financial performance based on ROA.

According to the results of second regression analysis (Panel B), liquidity and growth variables do not have a significant impact on gross profit. The results on the remaining explanatory variables are qualitatively similar to the first model: Higher leverage and R\&D expenditures are negatively related to gross margin while larger size, exports, and past profitability are positively related to that variable. 
Table 4. Estimation results.

\begin{tabular}{|c|c|c|c|c|c|c|}
\hline \multicolumn{7}{|c|}{ Panel A: Dependent variable: Return on Assets } \\
\hline Variable & Coef. & Robust Std. Err. & $t$ & $p>t$ & {$[95 \%$ Co } & Interval] \\
\hline Leverage & -0.12 & 0.01 & -11.47 & 0.00 & -0.14 & -0.10 \\
\hline Liquidity & 0.01 & 0.00 & 3.17 & 0.00 & -0.02 & -0.01 \\
\hline Size & 0.01 & 0.00 & 10.12 & 0.00 & 0.01 & 0.02 \\
\hline Exports & 0.02 & 0.00 & 4.81 & 0.00 & 0.01 & 0.03 \\
\hline R\&D & -0.23 & 0.12 & -1.86 & 0.06 & -0.47 & 0.01 \\
\hline Growth & 0.01 & 0.00 & 4.04 & 0.00 & 0.01 & 0.02 \\
\hline $\mathrm{ROA}_{t-1}$ & 0.15 & 0.01 & 13.57 & 0.00 & 0.13 & 0.18 \\
\hline Constant & -0.21 & 0.03 & -7.52 & 0.00 & -0.27 & -0.16 \\
\hline$N$ & 3346 & & & & & \\
\hline$F$ statistic & 102.11 & & & & & \\
\hline Prob $>F$ & $<0.001$ & & & & & \\
\hline R-squared & 0.23 & & & & & \\
\hline \multicolumn{7}{|c|}{ Panel B: Dependent variable: Gross Margin } \\
\hline Variable & Coef. & Robust Std. Err. & $t$ & $p>t$ & [95\% Co & Interval] \\
\hline Leverage & -0.09 & 0.02 & -3.49 & 0.00 & -0.14 & -0.04 \\
\hline Liquidity & 0.004 & 0.01 & 0.33 & 0.74 & -0.03 & 0.02 \\
\hline Size & 0.03 & 0.00 & 13.18 & 0.00 & 0.02 & 0.03 \\
\hline Exports & 0.07 & 0.01 & 6.65 & 0.00 & 0.05 & 0.08 \\
\hline R\&D & -1.66 & 0.25 & -6.72 & 0.00 & -2.15 & -1.18 \\
\hline Growth & -0.01 & 0.00 & -1.11 & 0.27 & -0.01 & 0.00 \\
\hline $\mathrm{GM}_{t-1}$ & 0.01 & 0.00 & 2.98 & 0.00 & 0.00 & 0.01 \\
\hline Constant & -0.22 & 0.04 & -5.74 & 0.00 & -0.30 & -0.15 \\
\hline N & 3333 & & & & & \\
\hline$F$ statistic & 38.83 & & & & & \\
\hline Prob $>F$ & $<0.001$ & & & & & \\
\hline R-squared & 0.19 & & & & & \\
\hline \multicolumn{7}{|c|}{ Panel C: Dependent variable: Tobin's Q } \\
\hline Variable & Coef. & Robust Std. Err. & $t$ & $p>t$ & {$[95 \%$ Co } & Interval] \\
\hline Leverage & 0.56 & 0.17 & 3.31 & 0.00 & 0.23 & 0.90 \\
\hline Liquidity & 0.06 & 0.03 & 1.86 & 0.06 & -0.13 & 0.10 \\
\hline Size & 0.03 & 0.02 & 1.37 & 0.17 & -0.01 & 0.06 \\
\hline Exports & -0.04 & 0.08 & -0.50 & 0.62 & -0.20 & 0.12 \\
\hline R\&D & 0.88 & 1.05 & 0.84 & 0.40 & -1.17 & 2.93 \\
\hline Growth & -0.03 & 0.02 & -1.40 & 0.16 & -0.07 & 0.01 \\
\hline $\mathrm{TQ}_{t-1}$ & 0.99 & 0.56 & 1.78 & 0.08 & -0.10 & 2.09 \\
\hline Constant & 0.85 & 0.34 & 2.54 & 0.01 & 0.19 & 1.5 \\
\hline$N$ & 3345 & & & & & \\
\hline$F$ statistic & 3.6 & & & & & \\
\hline Prob $>F$ & $<0.001$ & & & & & \\
\hline R-squared & 0.10 & & & & & \\
\hline
\end{tabular}

The results of the third model (Panel C) indicate that the majority of the explanatory variables do not have a statistically significant impact on firm financial performance as measured by Tobin's $Q$. Contrary to the first two models, the sign of the leverage variable is a positive sign that firms that carry higher amounts of interest bearing debt have higher Tobin's $Q$ values. On the other hand, liquidity has a positive impact on Tobin's $Q$. Finally, a firm's Tobin's $Q$ is positively related to its lagged value. The coefficients of the remaining variables are not significantly different from zero.

Overall, these empirical results suggest that several firm specific factors play a significant role in shaping financial performance and hence competitiveness for Turkish firms. The analysis so far assumed that the observed individual panel level effects are uncorrelated with the lagged dependent variable. To investigate how crucial this assumption is for our results, we followed [30] and replicated 
the analysis by using Arellano-Bond dynamic generalized method of moments (GMM) estimation approach. The results are were qualitatively the same.

\section{Conclusions}

The purpose of this study was to investigate the factors affecting firm competitiveness in an emerging market-Turkey. A firm's competitiveness was proxied by its financial performance as measured by return on assets (ROA), gross margin (GM) and Tobin's $Q(T Q)$. The period of analysis covered the years between 2005 and 2014 and the sample consisted of 359 listed firms per year on the average and a total of 3591 firm-years of observations. The results of panel regressions with fixed effects and robust standard errors showed that several firm specific variables have a significant impact on the financial performance of the companies in the sample.

The first finding that emerged from the analysis is that leverage has a significant impact on the three financial performance measures employed. Consistent with $[26,28]$, a negative relationship was documented between debt ratio and two measures of financial performance including return on assets and gross margin. On the contrary, the sign of the leverage variable was positive for the Tobin's $Q$ regression, meaning that firms employing higher amounts of external debt in their capital structure enjoy higher levels of Tobin's Q. Overall, these results suggest that leverage has a negative impact on current profitability but a positive impact on the investors' expectations about future profitability. Another result that emerged from the empirical analysis is that liquidity as measured by the firm's current ratio has a positive impact on return on assets and Tobin's $Q$ levels, consistent with [16,29].

The size of the firm has been found to have a positive and significant effect on both measures of current profitability, return on assets and gross margin. However, the size variable does not have a significant impact on Tobin's Q. These findings contradict those by [30] and suggest that Turkish firms benefit from economies of scale so that larger firms enjoy higher levels of current profitability. However, larger size is not perceived as a significant factor for investors in terms of the firm's potential about future profitability. Consistent with the expectations and prior literature [32], exporting firms have been demonstrated to have higher profitability compared to non-exporting firms. However, contrary to the expectations, the $R \& D$ variable is a negative sign, meaning that firms that invest more on research and development activities have lower return on assets and gross margin values. This finding, which contradicts results from previous studies [33], suggests that the increase in productivity as a result of $R \& D$ investments is offset by these R\&D expenditures' impact on the companies' net income and gross profit figures. Finally, growth has been documented to have a positive impact on return on assets and all three measures of financial performance have been found to be positively related to their lagged values. These results are in line with findings from previous studies in the finance literature [30,34].

Our results carry important implications for managers who are curious about the information related to the factors affecting the financial performance and competitiveness of the companies they are running. Overall, the results suggest that several firm specific factors are significant in explaining variations in the financial performance and competitiveness of Turkish firms. Financial managers could take these results into consideration for decision making and use various instruments to control some of the firm characteristics to obtain more favorable performance outcomes. For instance, liquidity is a desirable factor to improve firms' competitiveness. Similarly, investigating some overseas opportunities could be desirable as exports have a positive effect on financial performance. Expanding the scope of the operations and achieving a larger firm size could also be beneficial. All in all, decision makers should think beyond cost reduction and industry analysis and consider additional firm specific factors to improve the financial performance of the firms they are running.

The analysis results derived from this study were helpful in exploring the relationship between firm competitiveness or financial performance and several firm specific variables including leverage, liquidity, firm size, international sales, R\&D expenditures and growth. However, this study also suffers from some limitations and further studies, both quantitative and qualitative in nature, would be helpful 
to gain more insight on the relationship between financial performance and several firm-specific factors. First, the explanatory power of the regression models was not very high especially for the model using Tobin's $Q$ as the dependent variable. This could be due to the fact that scope limitations as well as data constraints forced the authors to only consider a limited set of explanatory variables. Hence, exploring the impact of additional explanatory variables such as corporate governance, capital expenditures or firm age could be a fruitful avenue for further research. Second, the results of the study were based on data from a single country; hence, another suggestion for further research could be to conduct a comparative study employing data from other emerging market firms so that the results become more generalizable. Extensive case studies investigating the experiences of individual firms could also be helpful in gaining more insight on the determinants of financial performance and could even be used to develop theoretical models. A final suggestion for further research could be to conduct a similar analysis at the group level rather than at the firm level since the majority of Turkish firms are affiliated with large business groups.

Conflicts of Interest: The author declares no conflict of interest.

\section{Abbreviations}

The following abbreviations are used in this manuscript:

GM Gross margin

R\&D Research and development

ROA Return on assets

SIC Standard industrial classification

TQ Tobin's Q

\section{References}

1. Porter, M.E. The Competitive Advantage of Nations; Free Press: New York, NY, USA, 1990.

2. Lall, S. Competitiveness, Technology and Skills; Edward Elgar Publishing: Cheltenham, UK, 2001.

3. Buckley, P.J.; Pass, C.L.; Prescott, K. Measures of international competitiveness: A critical survey. J. Mark. Manag. 1988, 4, 175-200. [CrossRef]

4. Liargovas, P.; Skandalis, K. Factors affecting firm competitiveness: The case of Greek industry. Eur. Inst. J. 2010, 2, 184-197.

5. Depperu, D.; Cerrato, D. Analyzing International Competitiveness at the Firm Level: Concepts and Measures; Working Paper No. 32; Quaderni del Dipartimento di Scienze Economiche e Sociali, Università Cattolica del Sacro Cuore, Piacenza, 2005. Available online: http://dipartimenti.unicatt.it/dises-wp_azzurra_05_32.pdf (accessed on 3 January 2016).

6. Barney, J. Resource-based theories of competitive advantage: A ten year retrospective on the resource based view. J. Manag. 2001, 27, 643-650. [CrossRef]

7. Levinthal, D. Strategic Management and the Exploration of Diversity. In Resource-Based and Evolutionary Theories of the Firm; Montgomery, C.A., Ed.; Kluwer: Norwell, MA, USA, 1995.

8. Teece, D. Internal organization and economic performance: An empirical analysis of the profitability of principal firms. J. Ind. Econ. 1981, 30, 173-199. [CrossRef]

9. Lev, B. Some economic determinants of time series properties of earnings. J. Account. Econ. 1983, 13, 31-48. [CrossRef]

10. Lipe, R.; Kormendi, R. Mean reversion in annual earnings and its implications for security valuation. Rev. Quant. Finance Account. 1994, 4, 27-46. [CrossRef]

11. Capon, N.; Farley, J.U.; Hoenig, S. Determinants of financial performance: A meta-analysis. Manag. Sci. 1990, 36, 1143-1159. [CrossRef]

12. Yurtoglu, B.B. Persistence of Firm-Level Profitability in Turkey. Appl. Econ. 2004, 36, 615-625. [CrossRef]

13. Giovanis, E.; Ozdamar, O. Facoltà di Economia, Università degli Studi di Verona. Determinants of Profitability: Evidence from US Firms. Unpublished work, 2014. 
14. Tailab, M.M. Analyzing Factors Effecting Profitability of Non-Financial U.S. Firms. Res. J. Finance Account. 2014, 5, 17-26.

15. Goddard, J.; Tavakoli, M.; Wilson, J.O.S. Determinants of profitability in European manufacturing and services: Evidence from a dynamic panel model. Appl. Financ. Econ. 2005, 15, 1269-1282. [CrossRef]

16. Pervan, M.; Visic, J. Influence of firm size on its business success. Croat. Oper. Res. Rev. 2012, 3, $213-223$.

17. Lalinsky, T. Firm Competitiveness Determinants: Results of a Panel Data Analysis. 2013. Available online: http://papers.ssrn.com/sol3/papers.cfm?abstract_id=2548947 (accessed on 3 January 2016).

18. Mirza, S.A.; Javed, A. Determinants of financial performance of a firm: Case of Pakistani stock market. J. Econ. Int. Finance 2013, 5, 43-52. [CrossRef]

19. Kakani, R.K.; Saha, B.; Reddy, V.N. Determinants of Financial Performance of Indian Corporate Sector in the Post-Liberalization Era: An Exploratory Study. National Stock Exchange of India Limited, NSE Research Initiative Paper No. 5. 2001. Available online: http:/ / ssrn.com/abstract=904983 (accessed on 3 January 2016).

20. Gurbuz, A.O.; Aybars, A.; Kutlu, O. Corporate governance and financial performance with a perspective on institutional ownership: Empirical evidence from Turkey. J. Appl. Manag. Account. Res. 2010, 8, 21-38.

21. Dogan, M. Does Firm Size Affect the Firm Profitability? Evidence from Turkey. Res. J. Finance Account. 2013, 4, 53-59.

22. Karabag, S.F.; Lau, M.C.K.; Suvankulov, F. Determinants of firm competitiveness: case of the Turkish textile and apparel industry. J. Text. Inst. 2014, 10, 1-11. [CrossRef]

23. Ghosh, A.; Jain, P.C. Financial leverage changes associated with corporate mergers. J. Corp. Finance 2000, 6, 377-402. [CrossRef]

24. Roden, O.; Lewellen, W. Corporate capital structure decisions: Evidence from leveraged buyouts. Financ. Manag. 1995, 24, 76-87. [CrossRef]

25. Taub, A. Determinants of firm's capital structure. Rev. Econ. Stat. 1975, 57, 410-416. [CrossRef]

26. Gleason, K.C.; Mathur, L.K.; Mathur, I. The interrelationship between culture, capital structure and performance: Evidence from European Retailers. J. Bus. Res. 2000, 50, 185-191. [CrossRef]

27. Majumdar, S.K.; Chhibber, P. Capital structure and performance: Evidence from a transition economy on an aspect of corporate governance. Public Choice 1999, 98, 287-305. [CrossRef]

28. Simerly, R.; Li, M. Environmental dynamism, financial leverage and performance: A theoretical integration and empirical test. Strateg. Manag. J. 2000, 21, 31-49. [CrossRef]

29. Goswami, S.; Sarkar, A. Liquidity, profitability analysis of Indian airways sector-An empirical study. Int. J. Res. Commer. Manag. 2011, 2, 116-122.

30. Loderer, C.F.; Waelchli, U. Firm Age and Performance. SSRN Working Paper No. 1342248. 2010. Available online: http:/ / papers.ssrn.com/sol3/papers.cfm?abstract_id=1342248 (accessed on 3 January 2016).

31. Cooley, T.F.; Quadrini, V. Financial markets and firm dynamics. Am. Econ. Rev. 2001, 91, 1286-1310. [CrossRef]

32. Wagner, J. Exports and Productivity: A Survey of the Evidence from Firm Level Data. World Econ. 2007, 30, 60-82.

33. Kafouros, M.I. R\&D and productivity growth: Evidence from the UK. Econ. Innov. New Technol. 2005, 14, 479-497.

34. Abor, J. The effect of capital structure on profitability: An empirical analysis of listed firm in Ghana. J. Risk Finance 2005, 6, 438-445.

35. Campbell, J.Y. Understanding risk and return. J. Polit. Econ. 1996, 104, 298-345. [CrossRef]

36. Greene, W. Econometric Analysis, 7th ed.; Prentice Hall: Englewood Cliffs, NJ, USA, 2011.

37. Campbell, J.Y.; Hilscher, J.; Szilagyi, J. In search of distress risk. J. Finance 2008, 63, 2899-2939.

38. White, $\mathrm{H}$. A heteroskedasticity-consistent covariance matrix estimator and a direct test for heteroskedasticity. Econometrica 1980, 48, 817-838. [CrossRef]

39. Lehmann, D.R.; Gupta, S.; Steckel, J. Marketing Research; Addison-Wesley: Reading, MA, USA, 1988.

(C) 2016 by the author; licensee MDPI, Basel, Switzerland. This article is an open access article distributed under the terms and conditions of the Creative Commons Attribution (CC-BY) license (http:/ / creativecommons.org/licenses/by/4.0/). 